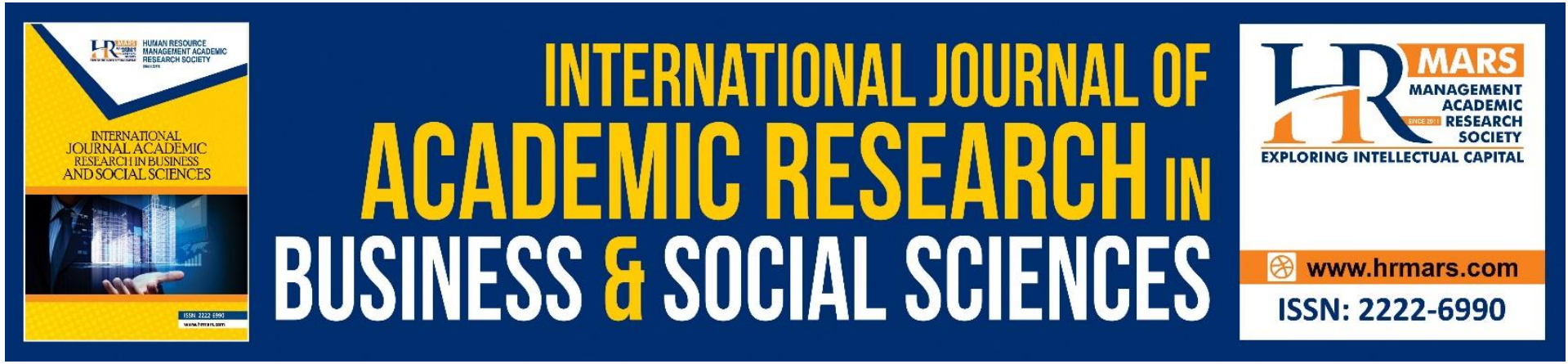

\title{
Strategies Used to Learn English Among Successful Language Learners
}

Muhammad Syamil Yahya, Nadrah Zainal Abidin, Siti Mahirah Ab Wahab, Ahmad Farit Mazlan \& Harwati Hashim

To Link this Article: http://dx.doi.org/10.6007/IJARBSS/v11-i7/10592

DOI:10.6007/IJARBSS/v11-i7/10592

Received: 21 May 2021, Revised: 24 June 2021, Accepted: 14 June 2021

Published Online: 29 July 2021

In-Text Citation: (Yahya et al., 2021)

To Cite this Article: Yahya, M. S., Abidin, N. Z., Wahab, S. M. A., Mazlan, A. F., \& Hashim, H. (2021). Strategies Used to Learn English Among Successful Language Learners. International Journal of Academic Research in Business and Social Sciences, 11(7), 1344-1359.

Copyright: (c) 2021 The Author(s)

Published by Human Resource Management Academic Research Society (www.hrmars.com)

This article is published under the Creative Commons Attribution (CC BY 4.0) license. Anyone may reproduce, distribute, translate and create derivative works of this article (for both commercial and non-commercial purposes), subject to full attribution to the original publication and authors. The full terms of this license may be seen at: http://creativecommons.org/licences/by/4.0/legalcode

Vol. 11, No. 7, 2021, Pg. 1344 - 1359

Full Terms \& Conditions of access and use can be found at http://hrmars.com/index.php/pages/detail/publication-ethics 


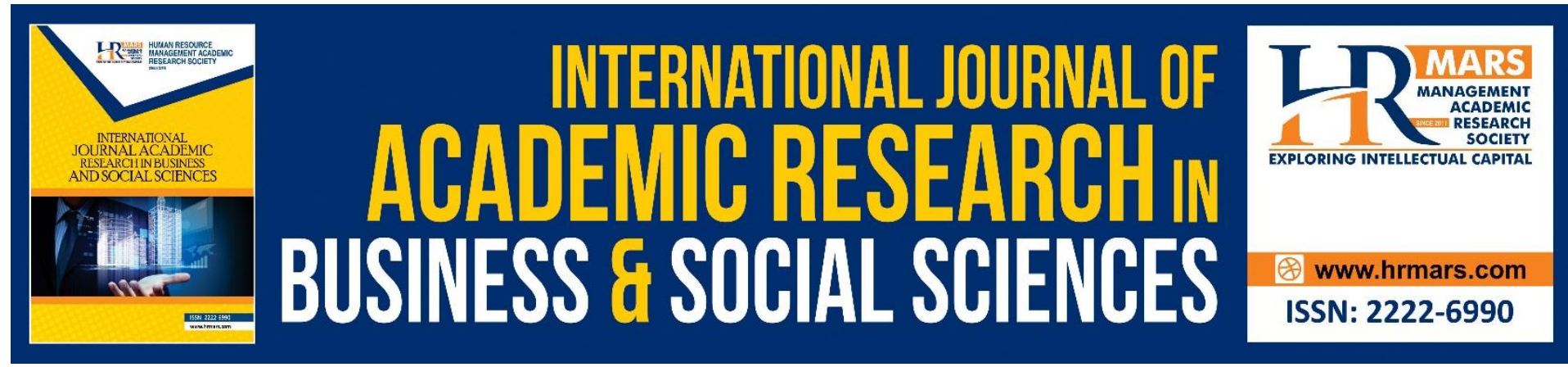

\title{
Strategies Used to Learn English Among Successful Language Learners
}

\author{
Muhammad Syamil Yahya, Nadrah Zainal Abidin, Siti Mahirah \\ Ab Wahab, Ahmad Farit Mazlan \& Harwati Hashim \\ Faculty of Education, Universiti Kebangsaan Malaysia
}

\begin{abstract}
Successful language learners, especially for the second language, are generally recognised for employing different learning strategies. Even so, not so many learning strategies to further improve their listening skills have been discussed. Thus, this study aims to identify and explore the strategies employed by successful learners among the Teaching English as a Second Language (TESL) degree holders who are teaching in various education institutions in Malaysia, primarily on listening skills. The quantitative method was applied in this study. An online survey was conducted with the involvement of 58 participants who are Teaching English as a Second Language (TESL) degree holders teaching in various education institutions in Malaysia. The survey questions were adapted from the Language Learning Strategy Use Survey, developed by Cohen, Oxford \& Chi (2002). Findings revealed that most of the respondents; (i)prefer to use media to heighten their exposure to the target language; (ii) form words association with the familiar sound of words in the target language; (iii)pay special attention to specific aspects of the language prior to the conversation; and, (iv)utilized all compensation strategies when they the meaning does not get through. The findings of this study could help teachers to enrich their learning experience not only as educators but also as a good language learner. When it comes to good language learners and language learning strategies, both teachers and learners' roles are mutually dependent and crucial. Teachers should be able to identify the strategies that suit their learners well, and guide them in applying various strategies accordingly. Based on the results, further study could be conducted to identify the suitable activities that would help the learners to improve their listening skills.
\end{abstract}

Keywords: Learning Strategies, Successful Language Learners, Listening Skills, English as a Second Language (ESL).

\section{Introduction}

English is used widely for multiple purposes and is a link language among various countries. The widespread use of the language also resulted in the nativisation of English among nonnative speakers (Thirusanku \& Yunus, 2014). For instance, Singaporean communicate with their native version of English, called Singlish. The recognition of the language is vital for accepting the citizen and developing the sense of belonging in using the language in their daily communication. In Malaysia, English was never referred to as one of the Malaysian languages. 
Even so, English is given recognition in the national education system. It has been taught widely and is one of the compulsory subjects for the students in each level of education to communicate in the language. The credibility of the language is also given through the major national examinations such as Pentaksiran Tingkatan Tiga (PT3) and Sijil Pelajaran Malaysia (SPM).

However, with the comprehensive measures that the government has taken, the level of English competency among Malaysian is still below par from the expectations. The National Graduate Employability Blueprint Report highlighted the problem with the fact that over 50 per cent of the graduates' lack competencies in subject knowledge, language skills (English), communications skills, and work attitudes (Selvaratnam, 2019). In addition, the survey from Jobstreet.com reveals the quality of the graduates, which is only average and poor level of English acquisition. These lead to the failure of the graduates to secure employment in critical sectors, which demand them to have a good command of English to perform globally (Ting et al., 2017). This imbalance between demand and supply of good human capital for sector needs obstructs the nation's will to be a self-sufficient, innovative and export-oriented highincome country.

In order to achieve the required standards, Malaysian University English Test (MUET) was developed as a measuring tool of a student's proficiency at the undergraduate level. This to ensure students are able to cope with the linguistic requirements of the courses offered at their tertiary institutions. Those who intend to further their studies abroad are obligated to undergo the Test of English as Foreign Language (TOEFL) and International English Language Testing System (IELTS) and achieve the required score as evidence of their language ability at the entry point into a university. However, the excellent score from these tests does not reflect the graduates as complete successful language learners. A previous study shows the mismatch between a test score and the student's actual performance in writing and speaking during the course (Abidin \& Jamil, 2015). Surprisingly, some students do not make the mark performing well in writing and speaking, and vice versa. These could be related to their choice of language learning strategies. Hashim et al (2018) identified that successful language learners are aware of different language learning strategies they employ to acquire the intended language. These multiple strategies are implied in the acceptable amount of numbers to suit their preferences (Rubaai et al., 2019). Hence, educators should have the indispensable ability to identify suitable language learning strategies that meet their students' preferences.

The previous studies show the questionable level of English competency among the graduates, especially the degree holders. After years of learning English, they are expected to perform well in a real-world situation, requiring them to apply and comprehend the language. Unfortunately, the competency level of English among the degree holders is unsatisfying. It does not match with the job specification in the critical sectors.

Inability to identify suitable language learning strategies is one of the problems of second language learners. Undergoing the wrong strategies would disrupt the motivation and the process of acquiring all the skills in the language. Moreover, the status of English as a second language put emphasis on Bahasa Melayu as the national language. Hence, learners should be able to verify their preferences in learning the second language as it will determine their 
strategies to learn the second language and keep them motivated to acquire English just as they acquire Bahasa Melayu.

Language acquisition should occur in all aspects of the language. However, there is an imbalance in language skills competency among the English learners and listening competency is one of them. As limited studies were conducted on listening skills competency, this is a good chance of exploration to help the learners and educators improve the acquisition process. Thus, the objective of this study is:

- to identify the language learning strategies of successful language learners among degree holders.

This can offer new insight for the learners and educators to try various strategies to improve language competency. In addition, this study emphasises the learning strategies for listening skills. The results could be an added value for the previous studies that were conducted on this particular skill.

\section{Literature Review Definition of LLS}

There are thousands of languages around the globe. The importance of each language varies according to every ethnicity, country and situation. English as an example is an official language for a few countries and also widely used around the world. As learning languages is an essential part of growth, many questions arise about how a language should be acquired or learned. Because it is seen as an imperative portion of dialect learning, inquire about dialect learning methodologies has expanded since the late 1970 . These include the process of investigating how language learners process languages and the best strategies for them.

Bialystock (1987) defined language learning strategies as a way to explore necessary information for learners to improve competence in learning a language. Wenden (1987) defined language learning strategy as learning and directing the meaning of a moment or remote dialect, cognitive hypothesis, and the emotional see, such as learners' inspiration and state of mind. Cohen (2011) defined language learning strategy as thoughts and actions, consciously selected by learners to assist them in learning and using the language in general, and in completion of specific language tasks. O'Malley and Chamot (1990) defined it as the special thoughts or behaviours that learners consciously employ to help them comprehend, learn, or retain new information. Meanwhile, according to Oxford (1985), it is an action taken by learners to make the process of learning a target language more meaningful. Therefore, it can be said that language learning strategies are conscious actions taken by learners to make learning more efficient. This is achieved by utilising multiple strategies based on their preferences.

\section{Categorisation of LLS}

Rubin (1985) classified language learning strategies into two categories which are the direct and indirect strategies. The direct strategies consisted of 1 ) clarification verification 2) monitoring 3) memorization 4) guessing inductive referencing 5) deductive reasoning 6) practice. On the other hand, indirect strategies involve creating opportunities for practice and production tricks. 
Meanwhile, Chamot \& O'Malley (1987) in their research has identified that language learning strategies were partitioned into three primary categories. The first category is metacognitive which refers to learners planning their language learning. The second category which is cognitive, refers to thinking about the language learning process. The third category is social affective which refers to evaluating the outcome of their own learning.

As to date, Rebecca Oxford inventories of LLS has been mostly used and referred to in the field of language learning strategies. Oxford (1990) classified language learning strategies into two broad categories which are direct strategies and indirect strategies. The direct strategies are sub-divided into 3 sub categories which are 1) memory strategy (creating mental linkages, applying images and sounds, reviewing well and employing action), 2) cognitive strategies (practising, receiving and sending messages, analysing and reasoning and creating structure for input and output) and 3) compensation strategies (guessing intelligently and overcoming limitations in speaking and writing). Meanwhile, indirect strategies are subdivided into three categories which are 1) metacognitive strategies (centring your learning, arranging and planning your learning and evaluating your learning), 2) affective strategies (lowering your anxiety, encouraging yourself and taking your emotional temperature) and 3) social strategies (asking questions, cooperating with others and empathizing with others).

\section{Good Language Learners}

The characteristics of a Good Language Learner was first introduced and presented in a seminar by Joan Rubin in 1975 in order to bridge the gap between good and poor language learners. Rubin believed that individuals have the same capabilities to learn the second language as they did for the first one. However, it was observed that some learners were able to learn the language quickly compared to others (Rubin, 1975). Hence, the researchers believed that some of the traits presented by the good language learners can be taught to assist the less successful language learner. 


\section{Rubin and Thompson's Characteristics of a Good Learner (1983)}

1. Good learners find their own way.

2. Good learners organise information about language.

3. Good learners are creative and experiment with language.

4. Good learners make their own opportunities and find strategies for getting practice in using the language inside and outside the classroom.

5. Good learners learn to live with uncertainty and develop strategies for making sense of the target language without wanting to understand every word.

6. Good learners use mnemonics (rhymes, words associations, etc to recall what has been learned).

7. Good learners make errors.

8. Good learners use linguistic knowledge including the knowledge of their first language in mastering a second language.

9. Good learners let the contect (extra linguistics knowledge and knowledge of the world) help them in comprehension.

10. Good learners learn to make intelligent guesses.

11. Good learners learn chunk of language as a whole and formalised routine to help them learn "beyond their competence."

12. Good learners learn production techniques (techniques of keeping conversation going).

13. Good learners learn different styles of speech and writing and learn to vary their language according to the formality of the situations.

Figure 1: Adapted from Nunan,David (2000) Language Teaching Methodology ,Harlow, Pearson Education Ltd.Page 171

Based on Rubin and Thompson (1983), a good language learner is considered an individual who strategizes learning, resourceful, determined, persevere, utilises a specific learning technique, and uses different approaches in learning speaking and writing. Similarly, Oxford (1990) stated that successful language learners are individuals who could monitor their emotions and attitudes while learning the language. She further added that learners' behaviour, ability, and learning strategy are vital in assisting learners' understanding of the complexity of the language.

On the other hand, according to Nunan (2000), the most significant characteristics of good language learners are willingness to take risks, utilising all the opportunities to practice the language whenever and wherever possible and also to get involved in student-centred activities that focus on form. 
Sharing a similar view, McDonough and Shaw (2003) highlighted the aspect of learners' attitude. They believed that successful language learners are those who are not afraid to guess and make mistakes when engaging in a conversation; instead, these learners use the opportunity to practice their language by utilising several strategies.

Meanwhile, Holden (2002) emphasised the learner's role to strategise their learning. He stated that independent learners strategise their learning efficiently, utilise all the opportunities to learn inside and outside the classroom, and know their part in regulating their learning process.

\section{Findings of Previous Study}

There was little previous research carried out on exploring the language learning strategies used among degree graduates. One of the strategies commonly used for this category of respondents is the affective strategies. Meanwhile, according to a study from Goh and Kwah (1997), they found out that Chinese students often use compensation strategies to learn a second language. This was taken from a study among Chinese students learning English in the United States and Singapore. Contrary to that, Magogwe and Oliver (2007) found that older students were more likely than younger students to utilise metacognitive methods. This is most probably due to their cognitive growth. Tang and Tian (2015) mentioned the results of their study on learners' language proficiency level variations in the usage of strategy categories suggested that learners utilised cognitive strategies more frequently as their language proficiency progressed.

Other than findings of language learning strategies used among graduates, the other findings and previous study that are significant to this study are the level of language competency among educators in Malaysia. Hanapi and Nordin (2014) in their study explored that the majority of respondents believe that the competency of lecturers is one of the reasons contributing to the graduate unemployment crisis. Kagaari (2007) in his study explored that not all lecturers in community college have an adequate level of English competencies. He agreed that good language competencies and skills are essential for all educators teaching at tertiary level. Similarly, lecturers also perceived general competencies in English language competencies to be important (Kamaruddin and Ibrahim, 2010).

In learning a foreign language, it is essential to master basic skills of language. Therefore, it is vital to identify the most suitable language learning strategies. Unfortunately, listening is one of the skills that are often not given much emphasis in learning a language. Selamat and Sidhu (2011) in a study conducted in different types of schools in Malaysia, stated that most schools paid less attention in developing students' listening skills compared to the other core skills in learning a language. This is also supported by a study by Tang (2018) where he summarised that the teaching of listening skills for English language had been neglected in many schools in Malaysia.

In terms of strategies used by language learners to practise listening skills, Abdalhamid (2012) mentioned that most learners prefer to use top-down strategies to improve their listening skills. Graham (2017) meanwhile mentioned that learners who use top-down and bottom-up processing strategically are mostly successful listeners. Therefore, learners need to know how to use those strategies wisely to acquire good listening skills in the language. 


\section{Methodology}

This study aimed to identify the language learning strategies for listening by the successful language learners among the degree holders. In achieving the aim, this study used quantitative as a research design which adopted survey as the research method. A survey is conducted on a sample or the entire population of people to describe the attitudes, opinions, behaviours or characteristics of the population (Creswell, 2003). According to Mclntyre (1999), surveys can also give information on attitudes that are quite difficult to measure using observational techniques. In this study, a cross-sectional survey, which is a type of survey that is administered at only one point of time was used.

\section{Sample}

The participants were 58 Teaching English as a Second Language (TESL) degree holders who are teaching in various education institutions in Malaysia. Non-probability sampling was used as the participants were a purposive sample. In purposive sampling, a researcher intentionally chooses the sample based on some previous knowledge about the population or based on a specific objective of the research (Creswell and Clark, 2011). According to Clark (2017), it is easier to implement and more effective. Additionally, in purposive sampling, the individuals are also selected based on some common characteristics or criteria. In this study, the respondents reflect the characteristics of successful language learners as they own a degree in TESL and are now currently teaching English at different educational institutions.

\section{Instrumentation}

This study used the LLS Use Survey, developed by Cohen, Chi and Oxford. The primary goal of this survey is to explore the strategies that they use in mastering a new language. Thus, a questionnaire was administered as an instrument for data collection. The adapted questionnaire consisted of 26 items that investigated the strategies that the respondents used in listening. Respondents were required to rate each strategy used based on five different statements; "This strategy does not fit for me", "I have tried this strategy and would do it again", "I use this strategy and like it" and "I've never used this strategy but am interested in it".

\section{Data Collection and Data Analysis}

In order to retrieve faster responses, Google Form was used as a platform, and the questionnaire link was distributed through the Whatsapp application. Once the responses were gathered, a descriptive statistical analysis was conducted to calculate frequencies and percentages in identifying the most and the least used learning strategies in listening based on two statements ("I have tried this strategy and would use it again" and "I use this strategy and I like it"). The descriptive analysis helps to present the findings of the survey question in a form that is easier to comprehend (Loeb et. al, 2017). In this study, the researcher used Microsoft Excel 2019 for Mac to analyse the data. The findings were then presented in four tables. 


\section{Findings \& Discussion}

\section{Table 1}

Strategies to increase my exposure to the target language

\begin{tabular}{|c|c|c|c|}
\hline \multirow[b]{2}{*}{ Statements } & \multicolumn{2}{|c|}{ Response } & \multirow[b]{2}{*}{ Total \% } \\
\hline & $\begin{array}{l}\text { I have tried this strategy } \\
\text { and would use it again }\end{array}$ & $\begin{array}{l}\text { I use this strategy and I } \\
\text { like it. }\end{array}$ & \\
\hline $\begin{array}{l}\text { Attend out-of-class events } \\
\text { where the new language is } \\
\text { spoken }\end{array}$ & $25.86(18)$ & $22.41(13)$ & 62.07 \\
\hline $\begin{array}{l}\text { Listen to talk shows on the } \\
\text { radio, watch TV shows, or } \\
\text { see movies in the target } \\
\text { language }\end{array}$ & $17.25(10)$ & $72.41(42)$ & $89.66 \%$ \\
\hline $\begin{array}{l}\text { Listen to the language in a } \\
\text { restaurant or store where } \\
\text { the staff speak the target } \\
\text { language. }\end{array}$ & $22.41(13)$ & $48.28(28)$ & $70.69 \%$ \\
\hline $\begin{array}{l}\text { Listen in on people who are } \\
\text { having conversations in the } \\
\text { target language to try to } \\
\text { catch the gist of what they } \\
\text { are saying }\end{array}$ & 27.57 (16) & $51.72(30)$ & $79.31 \%$ \\
\hline
\end{tabular}

Based on Table 1, in increasing their exposure to the target language, most of the respondents prefer listening to talk shows on the radio, watch TV shows or see movies in the target language (89.66\%). This is followed by listening in on people who are having conversations in the target language to try to catch the gist of what they are saying $(79.31 \%)$ and listening to the language in a restaurant or store where the staff speak the target language $(70.69 \%)$. The high percentages show that the respondents prefer to use all three direct strategies, which are memory, cognitive and compensation (Oxford, 1990). On the other hand, based on the table, it also shows that respondents apply fewer social learning strategies in increasing their exposure to the target language as the least preferred strategy was attending out-of-class events where the new language is spoken (62.07\%). Thus, it indicates that the respondents use a comprehensive range of listening strategies. As more effective learners, they apply topdown processing (Graham, 2017). It is also in line with the findings in the study conducted by Abdalhamid (2012). He found out that most learners prefer to use top-down strategies to improve their listening skills. 
Table 2

Strategies to become more familiar with the sounds in the target language.

\begin{tabular}{|c|c|c|c|}
\hline \multirow[b]{2}{*}{ Statements } & \multicolumn{2}{|c|}{ Response } & \multirow[b]{2}{*}{ Total \% } \\
\hline & $\begin{array}{l}\text { I have tried this strategy } \\
\text { and would use it again }\end{array}$ & $\begin{array}{l}\text { I use this strategy and I } \\
\text { like it. }\end{array}$ & \\
\hline $\begin{array}{l}\text { Practice sounds in the } \\
\text { target language that are } \\
\text { very different from sounds } \\
\text { in my own language to } \\
\text { become comfortable with } \\
\text { them }\end{array}$ & 24.14 (14) & $51.72(30)$ & 75.86 \\
\hline $\begin{array}{l}\text { Look for associations } \\
\text { between the sound of a } \\
\text { word or phrase in the new } \\
\text { language with the sound of } \\
\text { a familiar word }\end{array}$ & 27.59 (16) & $50.0(29)$ & 77.59 \\
\hline $\begin{array}{l}\text { Imitate the way native } \\
\text { speakers talk. }\end{array}$ & 31.03 (18) & $44.83(26)$ & 75.86 \\
\hline $\begin{array}{l}\text { Ask a native speaker about } \\
\text { unfamiliar sounds that I } \\
\text { hear }\end{array}$ & 32.76 (19) & 20.69 (12) & 53.45 \\
\hline
\end{tabular}

Based on Table 2, in order to become more familiar with the sounds in target language, most of the respondents look for associations between the sound of a word or phrase in the new language with the sound of a familiar word (77.59\%). This is followed by imitating how native speakers talk and practice sounds in the target that are very different from the sound in their own language, which share an equal percentage (75.86\%). From the findings in Table 2, it can be concluded that most of the respondents used memory strategy to become more familiar with the sounds in the target language. The high percentage of all the statements signifies that memory strategy is an effective strategy. Meanwhile, the least preferred strategy was to ask native speakers about unfamiliar sounds that they hear $(53.45 \%)$. This shows that the respondents apply less social strategy to become more familiar with the sounds in the target language. 


\section{Table 3}

Strategies to prepare to listen to conversation in the target language

\begin{tabular}{|c|c|c|c|}
\hline \multirow[b]{2}{*}{ Statements } & \multicolumn{2}{|c|}{ Response } & \multirow[b]{2}{*}{ Total \% } \\
\hline & $\begin{array}{l}\text { I have tried this strategy } \\
\text { and would use it again }\end{array}$ & $\begin{array}{l}\text { I use this strategy and I } \\
\text { like it. }\end{array}$ & \\
\hline $\begin{array}{l}\text { Pay special attention to } \\
\text { specific aspects of the } \\
\text { language; for example, } \\
\text { the way the speaker } \\
\text { pronounces certain } \\
\text { words. }\end{array}$ & 39.66 (23) & $48.28(28)$ & 87.93 \\
\hline $\begin{array}{l}\text { Try to predict what the } \\
\text { other person is going to } \\
\text { say based on what has } \\
\text { been said so far. }\end{array}$ & 32.76 (19) & $37.93(22)$ & 70.69 \\
\hline $\begin{array}{l}\text { Prepare for talks and } \\
\text { performances I will hear } \\
\text { in the target language by } \\
\text { reading some } \\
\text { background materials } \\
\text { beforehand }\end{array}$ & $36.20(21)$ & 39.66 (23) & 75.86 \\
\hline $\begin{array}{l}\text { Listen for key words that } \\
\text { seem to carry the bulk of } \\
\text { the meaning. }\end{array}$ & $36.20(21)$ & 46.55 (27) & 82.76 \\
\hline $\begin{array}{l}\text { Listen for word and } \\
\text { sentence stress to see } \\
\text { what native speakers } \\
\text { emphasise when they } \\
\text { speak }\end{array}$ & 32.76 (19) & 46.55 (27) & 79.31 \\
\hline $\begin{array}{l}\text { Pay attention to when } \\
\text { and how long people } \\
\text { tend to pause. }\end{array}$ & $22.41(13)$ & $22.41(13)$ & 44.83 \\
\hline $\begin{array}{l}\text { Pay attention to the rise } \\
\text { and fall of speech by } \\
\text { native speakers - the } \\
\text { 'music' of it. }\end{array}$ & $36.20(21)$ & $25.86(15)$ & 62.07 \\
\hline $\begin{array}{l}\text { Practice "skim listening" } \\
\text { by paying attention to } \\
\text { some parts and ignoring }\end{array}$ & 24.14 (14) & $41.38(24)$ & 65.52 \\
\hline
\end{tabular}




\begin{tabular}{l|ccc}
\hline others. & & & \\
\hline $\begin{array}{l}\text { Try to understand what I } \\
\text { hear without translating } \\
\text { it word-for-word. }\end{array}$ & $31.03(18)$ & $53.45(31)$ & 84.48 \\
\hline $\begin{array}{l}\text { Focus on the context of } \\
\text { what people are saying. }\end{array}$ & $34.48(20)$ & $48.28(28)$ & 82.76 \\
\hline $\begin{array}{l}\text { Listen for specific details } \\
\text { to see whether I can } \\
\text { understand them. }\end{array}$ & $37.93(22)$ & $44.83(26)$ & 82.76 \\
\hline
\end{tabular}

Based on Table 3, most of the respondents pay special attention to specific aspects of the language; for example, the way the speaker pronounces certain words as a strategy to prepare to listen to a conversation in the target language (87.93\%). It can be said that successful language learners prefer to apply cognitive and memory strategies to improve their listening skills. However, they do not solely depend on this type of strategy. The application of compensation strategies occurs alongside other strategies. The data shows a high percentage of the respondents who listen for keywords that seem to carry the bulk of the meaning $(82.76 \%)$, focus on the context of what people are saying $(82.76 \%)$, and listen for specific details to see whether they can understand the conversation (82.76\%). Interestingly, metacognitive strategies are also favoured by the respondents. $75.86 \%$ of them prepare for talks and performances they will hear in the target language by reading some background materials beforehand. Another metacognitive strategy implied is practice "skim listening" by paying attention to some parts and ignoring others $(65.52 \%)$, followed by paying attention to the rise and fall of speech by native speakers - the 'music' of it (62.07\%).

A high percentage of responses is recorded for multiple different strategies as preparation to listen to the target language conversation. The data indicates that the participants use more direct strategies (cognitive, memory and compensation) than indirect strategies (metacognitive and social). Almost all of the strategies listed received a high frequency of users, which are more than $50 \%$. Presumably, successful language learners can independently identify and recognise the suitable strategies to prepare themselves in listening. They can also integrate multiple strategies to comprehend the message they heard in the target language (Yunus et al., 2013). Since English is not their first language, it is expected for the learners to strategise themselves in comprehending the conversation. As these findings reflect the successful language learners with their ability to use some strategies without being instructed, strategies-based instructions are still needed in the classroom to get them familiarised with other strategies (Zhang, 2012). In a way, these findings call for the teachers' attention to give effective strategies-based instructions that would help learners to explore different strategies in preparation for listening. 


\section{Table 4}

Strategies for when I do not understand some or most of what someone says in the target language

\begin{tabular}{|c|c|c|c|}
\hline \multirow[b]{2}{*}{ Statements } & \multicolumn{2}{|c|}{ Response } & \multirow[b]{2}{*}{ Total \% } \\
\hline & $\begin{array}{l}\text { I have tried this strategy } \\
\text { and would use it again }\end{array}$ & $\begin{array}{l}\text { I use this strategy and I } \\
\text { like it. }\end{array}$ & \\
\hline $\begin{array}{l}\text { Ask speakers to repeat } \\
\text { what they said if it wasn't } \\
\text { clear to me. }\end{array}$ & $43.10(25)$ & 39.66 (23) & 82.76 \\
\hline $\begin{array}{l}\text { Ask speakers to slow down } \\
\text { if they are speaking too } \\
\text { fast. }\end{array}$ & $41.38(24)$ & 39.66 (23) & 81.03 \\
\hline $\begin{array}{l}\text { Ask for clarification if I } \\
\text { don't understand it the first } \\
\text { time around. }\end{array}$ & 39.66 (23) & $43.10(25)$ & 82.76 \\
\hline $\begin{array}{l}\text { Use the speakers' tone of } \\
\text { voices as a clue to the } \\
\text { meaning of what they are } \\
\text { saying. }\end{array}$ & $36.20(21)$ & $34.48(20)$ & 70.69 \\
\hline $\begin{array}{l}\text { Make educated guesses } \\
\text { about the topic based on } \\
\text { what has already been } \\
\text { said. }\end{array}$ & $37.93(22)$ & $44.83(26)$ & 82.76 \\
\hline $\begin{array}{l}\text { Draw on my general } \\
\text { background knowledge to } \\
\text { get the main idea. }\end{array}$ & $37.93(22)$ & $43.10(25)$ & 81.03 \\
\hline $\begin{array}{l}\text { Watch speakers' gestures } \\
\text { and general body language } \\
\text { to help me figure out the } \\
\text { meaning of what they are } \\
\text { saying. }\end{array}$ & 29.31 (17) & $58.62(34)$ & 87.93 \\
\hline
\end{tabular}

Based on Table 4, most respondents employed compensation strategies when they did not understand what someone says in a target language. The high percentage of all the strategies signify that compensation is an effective strategy. As stated by Oxford (1990) in regards to compensation strategies "it helps learners to overcome knowledge limitations in all four skills." In addition, compensation strategies are "also useful for more expert language users who occasionally do not know an expression"(pg 90). It can be seen that watching speakers' gestures and general body language is the most popular strategy (87.93\%) while using speakers' tone and voices is the least used strategy $(70.69 \%)$. This data corroborates with 
Oxford (1990), who stated 'linguistic clues are the bedrock of many correct guesses about the meaning of written passages' (p.91)'. However, in a similar study conducted among 30 adult learners in a higher learning institution (UiTM), the results showed that compensation strategies were employed on the average with "guessing" indicated as the most frequently used strategy (Ahmad \& Ismail,2013). Hence, as the respondents in this study are English language teachers and presumably with better language proficiencies, it can be said that good language learners are indeed using more learning strategies in learning the language.

\section{Conclusion}

Acquiring a language, especially a second language, is not an easy task. It took compassion, hard work and creativity to employ correct strategies for each barrier in mastering particular language skills. Based on the study, it shows that successful language learners are able to employ a wide range of strategies in the classroom and informal settings to master listening skills. The preferences of strategies depend on the situations they face. It is believed that this study could help to enrich limited past studies on language strategies on listening skills and offer different views for further study of the spectrum. Though successful language learners are able to identify and employ these strategies, strategies-based instruction from teachers, especially in classroom settings, is still needed. When it comes to good language learners and language learning strategies, we must bear in mind that both teachers and learners' roles are mutually dependent and crucial. Teachers should be able to identify the strategies that suit their learners well and direct them to apply various strategies accordingly. On the learners' side, they should realise that their dependency on teachers' instructions shapes them to become autonomous learners.

\section{References}

Abdalhamid, F. (2012). Listening comprehension strategies of Arabic-speaking ESL learners (Doctoral dissertation, Colorado State University).

Adler, E., and Clark, R. (2015) An Invitation to Social Research: How It's Done, 5th edn, Cengage Learning, Stamford, CT.

Ahmad, B. S., \& Ismail, R. (2013). Compensation learning strategies employed by adult ESL learners of a university in Malaysia. Procedia-Social and Behavioral Sciences, 90, 78-87.

Bialystok, E. (1978). A theoretical model of second language learning. Language Learning, 28(1), 69-83

Chamot, A. U., \& O'malley, J. M. (1987). The cognitive academic language learning approach: A bridge to the mainstream. TESOL quarterly, 21(2), 227-249.

Clark, R. (2017). Convenience Sample. The Blackwell Encyclopedia of Sociology, 1-2. doi:10.1002/9781405165518.wbeosc131.pub2

Creswell, J. W. (1994). Research design: Qualitative and quantitative approaches. Thousand Oaks. CA: Sage.

Creswell, J. W., \& Clark, V. L. P. (2011). Designing and conducting mixed method research. Thousand Oaks.CA: 2nd Sage.

Cohen, A. D. (2011). Second language learner strategies. Handbook of research in second language teaching and learning, 2(Part V), 681-698.

Cohen, A. D., Oxford, R. L., \& Chi, J. C. (2002). Language Strategy Use Survey. Minneapolis, $\mathrm{MN}$ : Center for Advanced Research on Language Acquisition, University of Minnesota. [In Cohen \& Weaver, 2006, pp. 68-74] 
Ellis, R. (1994). The study of second language acquisition. Oxford: Oxford University Press Graham, S. (2017). Research into practice: Listening strategies in an instructed classroom setting. Language Teaching, 50(1), 107-119.

Goh, C., \& Kwah, P. F. (1997). Chinese ESL students' learning strategies: A look at frequency, proficiency and gender. Hong Kong Journal of Applied Linguistics, 2(1), 39-53.

Hanapi, Z., \& Nordin, M. S. (2014). Unemployment among Malaysia graduates: Graduates' attributes, lecturers' competency and quality of education. Procedia-Social and Behavioral Sciences, 112, 1056-1063.

Hashim, H. U., Yunus, M. M., \& Hashim, H. (2018). Language Learning Strategies Used by Adult Learners of Teaching English as a Second Language (TESL). TESOL International Journal, 13(4), 39-48.

Holden, B. (2002). Listen and Learn. English Teaching Professional, 23, 18-20

Kaagari, J. R. K. (2007). Engineering lecturers' competencies and organisational behavior (OCB) at Kyambogo University. Journal of European Industry Training, 31, 9, 706-711.

Kamaruddin, W. N. W., \& Ibrahim, M. S. (2010, June). Lecturer efficacy, professional and general competencies of Malaysian polytechnic technical lecturers. In Proceedings of the Regional Conference on Engineering Education \& Research in Higher Education 2010 (pp. 27-32).

Loeb, S., Dynarski, S., McFarland, D., Morris, P., Reardon, S., \& Reber, S. (2017). Descriptive analysis in education: A guide for researchers. (NCEE 2017-4023). Washington, DC: U.S. Department of Education, Institute of Education Sciences, National Center for Education Evaluation and Re-gional Assistance.

Magogwe, J. M., \& Oliver, R. (2007). The relationship between language learning strategies, proficiency, age and self-efficacy beliefs: A study of language learners in Botswana. System, 35(3), 338-352.

McDonough, J., \& Shaw, C. (2003). Materials and methods in ELT. Oxford: Blackwell.

McIntyre, L. J. (1999). The practical skeptic: Core concepts in sociology. Mountain View, CA: Mayfield Publishing.

Nunan, D. (2000). Autonomy in language learning. Plenary presentation given at the ASOCOPI 2000 conference, Cartengena, Columbia.

O'Malley J. M., and Chamot, A. U. (1990) Learning Strategies in Second Language Acquisition. Cambridge: Cambridge University Press. Oxford,

Omar, A. H. (2012). Pragmatics of maintaining English in Malaysia's education system. English in Southeast Asia: Features, policy and language in use, 155-174.

Oxford, R. (1990). Language learning strategies: What every teacher should know. New York: Newbury House/Harper and Raw

Rigney, J. W. (1978). Learning strategies: A theoretical perspective. Learning strategies, 165205.

Rubaai, N., Hashim, H., \& Yunus, M. M. (2019). Identifying English Language Learning Strategies Used by Polytechnic Students. Religación, 4, 98-103.

Selamat, S., \& Sidhu, G. K. (2011). Student perceptions of metacognitive strategy use in lecture listening comprehension. Language Education in Asia, 2(2), 185-198.

Selvaratnam, V. (2019). Malaysia: National language policy and employability. International Higher Education, (96), 16-18.

Tang, K. N. (2018). The importance of soft skills acquisition by teachers in higher education institutions. Kasetsart Journal of Social Sciences. 
Tang, M., \& Tian, J. (2015). Associations between Chinese EFL graduate students' beliefs and language learning strategies. International journal of bilingual education and bilingualism, 18(2), 131-152.

Thirusanku, J., \& Yunus, M. M. (2014). Status of English in Malaysia. Asian Social Science, 10(14), 254.

Ting, S. H., Marzuki, E., Chuah, K. M., Misieng, J., \& Jerome, C. (2017). Employers' views on the importance of English proficiency and communication skill for employability in Malaysia. Indonesian Journal of Applied Linguistics, 7(2), 315-327.

Wenden, A. (1987). Metacognition: An expanded view on the cognitive abilities of $L 2$ learners. Language learning, 37(4), 573-597.

Wenden, A. (1987). Learner Strategies for Learner Autonomy. New York: York College, City University

Yunus, M. M., Sulaiman, N. A., \& Embi, M. A. (2013). Malaysian Gifted Students' Use of English Language Learning Strategies. English Language Teaching, 6(4), 97-109.

Abidin, Z. S. A., \& Jamil, A. (2015). Toward an English proficiency test for postgraduates in Malaysia. SAGE Open, 5(3), 2158244015597725.

Zhang, Y. (2012). The Impact of Listening Strategy on Listening Comprehension. Theory \& Practice in Language Studies, 2(3). 